\title{
Canadians balk at longer brand-name drug patents
}

$\mathrm{N}$ early two-thirds of Canadians oppose longer patents for brand-name drugs under a proposed trade deal with the European Union, according to a poll commissioned by the Council of Canadians.

Although $73 \%$ of respondents to the Environics poll supported the idea of free trade between Canada and the European Union, $65 \%$ were against plans to extend drug patents by two years under the coming Comprehensive Economic and Trade Agreement (CETA).

Opposition to this part of the agreement - which may increase drug costs for Canadians by as much as $\$ 1.65$ billion a year by delaying the release of cheaper generic medicines - cut across party lines, as well as age and geographic groups.

"This is consistent with polls we've done in the past," says Stuart Trew, trade campaigner for the Council of Canadians. "People are uncomfortable with these changes and I think that should be a strong message to the government that they don't have a mandate to make them."

The poll also asked if the federal government should have to hold public hearings across Canada before it can sign and ratify the deal. Some $80 \%$ of respondents agreed, with strong support for hearings across the political spectrum.

Prime Minister Stephen Harper signed on to CETA in principle on Oct. 18 , but neither party has made the precise wording of the deal public. Meanwhile, public consultation has been limited to largely one-way technical briefings on highlights of the pact, says Trew. "They weren't even recording questions in the minutes, so there's been no indication that these meetings have had any effect on the negotiations."

Representatives of brand-name pharmaceutical companies have welcomed

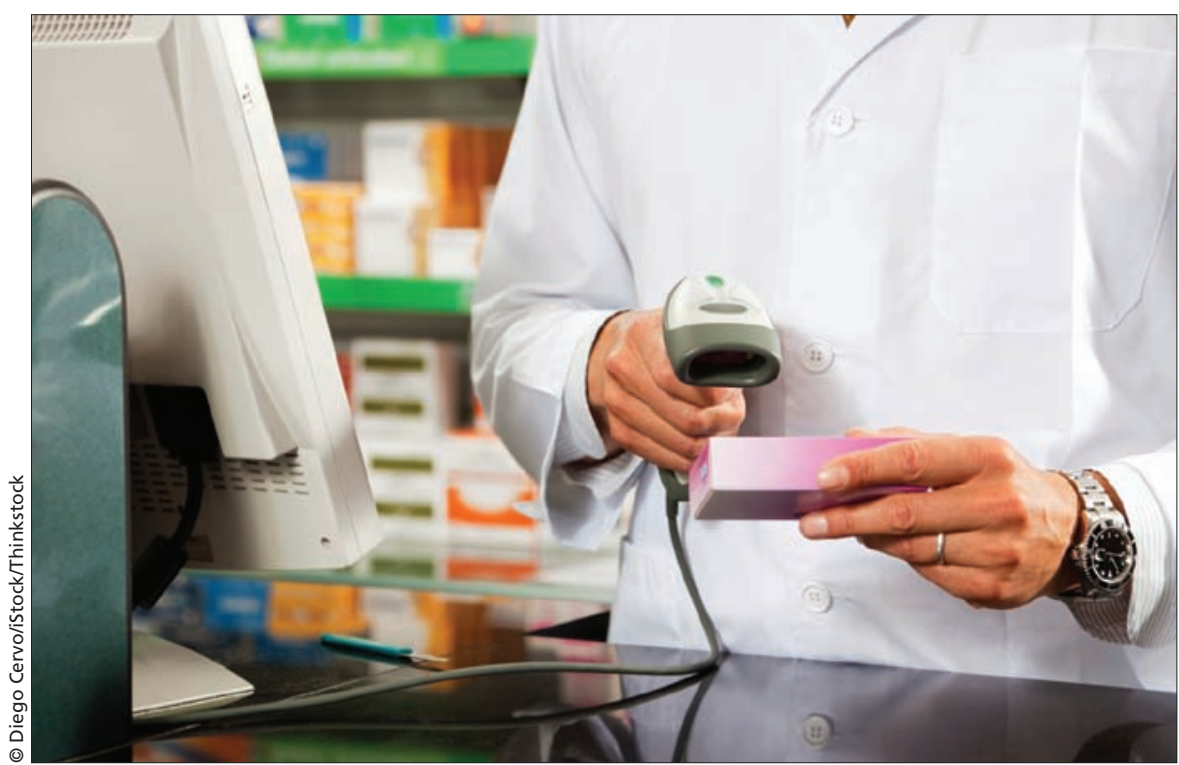

Longer patents for brand-name medicines may hike drug costs by as much as $\$ 1.65$ billion a year.

CETA, saying increased patent protection will compensate for Canada's lengthy drug approval process. They also contend the agreement will stimulate investment and clinical trials in Canada.

But according to a recent Canadian Centre for Policy Alternatives briefing, Canada already pays more for drugs than most other countries due to existing "industry-friendly intellectual property policies, which include a generous pricing system and broad protection of brand-name pharmaceuticals."

Meanwhile, Trew says brand-name drug manufacturers have consistently failed to meet past pledges to reinvest $10 \%$ of revenues in Canadian research and development. "History tells us there is no guarantee they will meet these new promises, and there's no way to hold them accountable if they don't."

The federal government may reimburse the provinces for any additional costs to stock their formularies as a result of the changes under CETA. But the move may be akin to rearranging deck chairs on a sinking ship. Ultimately, Canadian taxpayers will end up footing the bill, and people paying for drugs out-of-pocket or through private insurance will be hit twice, says Trew.

However, there may be potential for push-back at the provincial level, as CETA will work against efforts to contain costs through bulk purchasing and regulation of generic drug prices.

"We'd like to think the federal government will do a public hearing or review," says Trew. "But I think that's more likely to come from the provinces."

Before CETA takes effect, all provinces and territories, as well as the 28 European Union nations, must approve the deal.

The Environics telephone poll surveyed a random national sample of 1003 adults, and has a margin of error of $+/-3.1 \%, 19$ times out of 20 . Lauren Vogel, CMAJ

CMAJ 2014. DOI:10.1503/cmaj.109-4679 